\title{
KINERJA KARYAWAN: GAYA KEPEMIMPINAN, MOTIVASI, DAN LINGKUNGAN KERJA DI BANK
}

\author{
Mohammad Benny Alexandri ${ }^{1}$, Meita Pragiwani ${ }^{2}$, Eva Nopalina Panjaitan ${ }^{3}$ \\ Universitas Padjadjaran ${ }^{1}$, Sekolah Tinggi Ilmu Ekonomi Indonesia², Sekolah Tinggi Ilmu Ekonomi Indonesia ${ }^{3}$ \\ mohammad.benny@unpad.ac.id¹, meitasoetopo@gmail.com², evanopalina97@gmail.com³
}

\begin{abstract}
ABSTRAK
Penelitian ini bertujuan untuk mengetahui pengaruh gaya kepemimpinan, motivasi, dan lingkungan kerja terhadap kinerja karyawan PT. Bank Capital Indonesia (Kantor Pusat Operasional). Metode yang digunakan adalah menggunakan metode asosiatif kausal. Penelitian asosiatif kausal adalah studi yang bertujuan untuk mengetahui pengaruh antara dua variabel atau lebih. Penelitian ini menjelaskan pengaruh dan pengaruh hubungan dari variabel yang akan dipelajari. Objek penelitian ini adalah karyawan di PT. Bank Capital Indonesia, Tbk Kantor Pusat Operasional, tempat penulis mendistribusikan kuesioner tertulis untuk diberikan kepada karyawan PT. Bank Capital Indonesia, Tbk Kantor Pusat Operasional dijawab dengan menggunakan "Skala Likert". Dalam penelitian ini, 150 karyawan diambil responden pada Maret 2017. Alat analisis data yang digunakan dalam penelitian ini adalah analisis regresi linier berganda. Dari hasil penelitian diketahui bahwa ada pengaruh yang signifikan antara gaya kepemimpinan, motivasi, dan lingkungan kerja terhadap kinerja karyawan. Dari 3 (tiga) variabel penelitian yang dianalisis, bahwa variabel motivasi adalah variabel yang paling dominan mempengaruhi kinerja karyawan dan diikuti oleh variabel lingkungan kerja dan variabel gaya kepemimpinan.
\end{abstract}

Kata kunci: Gaya Kepemimpinan, Motivasi, Lingkungan Kerja, Kinerja

\begin{abstract}
This study aims to determine the effect of leadership style, motivation, and work environment on the performance of employees of PT. Bank Capital Indonesia (Operational Headquarters). The method used is using causal associative methods. Causal associative research is a study that aims to determine the influence between two or more variables. This study explains the influence and influence of the relationship of the variables to be studied. The object of this research is employees at PT. Bank Capital Indonesia, Tbk Operational Headquarters, where the author distributes written questionnaires to be given to employees of PT. Bank Capital Indonesia, Tbk Operational Headquarters is answered by using a "Likert Scale". In this study, 150 employees were taken by respondents in March 2017. The data analysis tool used in this research was multiple linear regression analysis. From the results of the study note that there is a significant influence between leadership style, motivation, and work environment on employee performance. Of the 3 (three) variables analyzed, that motivation variable is the most dominant variable affecting employee performance and followed by work environment variables and leadership style variables.
\end{abstract}

Keywords: Leadership Style, Motivation, Work Environment, Performance

\section{PENDAHULUAN}

Perbankan merupakan inti dari sistem keuangan di masing-masing negara Indonesia, yang telah memiliki beberapa undang-undang yang mengatur perbankan. 3 tahun 2004 tentang Bank Indonesia. Sektor perbankan memiliki peran yang berpengaruh pada kemajuan atau kemunduran ekonomi dalam suatu negara. Bank memainkan peran penting untuk meminimalkan risiko di dunia perbankan dan memberikan perlindungan terhadap dana publik di lembaga perbankan. Bank mengendalikan laju inflasi dengan mengendalikan jumlah uang dan barang yang beredar ke publik. Peningkatan jumlah bank dan unit pelaksana mereka memiliki potensi untuk mendorong bisnis sektor perbankan lebih kompetitif dan meningkatkan efisiensi dan kesehatan bank.

Selain modal, fasilitas dan infrastruktur, teknologi, dan peraturan yang berlaku, perusahaan atau organisasi membutuhkan kualitas Sumber Daya Manusia (SDM). Sumber daya manusia yang baik akan berkontribusi dengan baik dalam hal pencapaian 


\section{Kinerja Karyawan: Gaya Kepemimpinan, Motivasi, dan Lingkungan Kerja Di Bank (Mohammad Benny Alexandri, Meita Pragiwani, Eva Nopalina Panjaitan)}

produktivitas dan peningkatan kualitas, pencapaian visi dan misi perusahaan. Hal ini tampaknya baik dalam kehidupan rumah tangga, organisasi sosial, terutama ketika seseorang memasuki dunia kerja. Seseorang akan berinteraksi, dan masuk ke dalam bagian organisasi tempat dia bekerja. Menurut Robbins (2006) organisasi adalah unit sosial yang dikelola dengan sengaja yang terdiri dari dua atau lebih orang, yang berfungsi secara relatif berkelanjutan untuk mencapai tujuan bersama atau serangkaian tujuan.

Kinerja karyawan sangat mempengaruhi keberhasilan tujuan suatu organisasi, melihat pentingnya karyawan dalam suatu organisasi. Hal ini sesuai dengan pendapat Koopmans et al (2014) bahwa kinerja didefinisikan sebagai perilaku atau tindakan yang relevan dengan tujuan organisasi. Dapat dikatakan bahwa karyawan adalah aset organisasi yang berharga, maka kebutuhan akan dukungan dan pengembangan membuat kemampuan karyawan menjadi baik. Kinerja yang baik dapat dilihat dari hasil yang dapat, sesuai dengan standar organisasi. Salah satu upaya untuk meningkatkan kinerja karyawan dapat dilakukan dengan kebijakan dan arahan yang diterapkan dari pemimpin yang dapat diandalkan dan motivasi dan arahan yang tinggi. Kebijakan organisasi atau lembaga apa pun dalam memberikan aturan untuk mencapai tujuannya berbeda.

PT. Bank Capital Indonesia, Tbk adalah salah satu perusahaan yang bergerak di bidang perbankan yang harus berkompetisi dalam dunia perbankan yang semakin ketat. Untuk dapat bersaing, PT. Bank Capital Indonesia, Tbk harus selalu meningkatkan kinerja sumber daya manusia secara efisien dan efektif. Dalam hal ini kemampuan seorang pemimpin dalam memotivasi dan mengarahkan karyawan diperlukan untuk meningkatkan kinerja karyawan. Selain itu, lingkungan kerja dalam suatu perusahaan sangat penting untuk diperhatikan oleh perusahaan manajemen. Lingkungan kerja yang memuaskan bagi karyawan perusahaan akan mendorong karyawan untuk bekerja terbaik, termasuk dalam hal layanan optimal kepada pelanggan. Sehingga kinerja karyawan yang diharapkan dapat ditingkatkan, dan tujuan perusahaan dapat dengan mudah dicapai. Menurut Robbins (2006) organisasi adalah unit sosial yang dikelola dengan sengaja yang terdiri dari dua atau lebih orang, yang berfungsi secara relatif berkelanjutan untuk mencapai tujuan bersama atau serangkaian tujuan.

Menurut Simamora (2006) sumber daya manusia adalah aset organisasi yang paling penting dan membuat sumber daya organisasi lainnya bekerja. Oleh karena itu, keberadaan sumber daya manusia dalam suatu perusahaan sangat penting karena sumber daya manusia yang ada merupakan ujung tombak keberhasilan suatu perusahaan, terutama bagi perusahaan yang bergerak di bidang jasa. Prestasi suatu organisasi erat kaitannya dengan kualitas kinerja anggota di dalamnya. Untuk mempertahankan dan memaksimalkan kinerja anggota yang baik ada banyak hal yang mempengaruhi seperti kesejahteraan, pendidikan, pelatihan, motivasi, kepemimpinan, budaya organisasi, dan lingkungan kerja.

Kinerja karyawan sangat mempengaruhi keberhasilan tujuan suatu organisasi, melihat pentingnya karyawan dalam suatu organisasi. Hal ini sesuai dengan pendapat Koopmans et al (2014) bahwa kinerja didefinisikan sebagai perilaku atau tindakan yang relevan dengan tujuan organisasi. Dapat dikatakan bahwa karyawan adalah aset organisasi yang berharga, maka kebutuhan akan dukungan dan pengembangan membuat kemampuan karyawan menjadi baik. PT. Bank Capital Indonesia, Tbk adalah salah satu perusahaan yang bergerak di bidang perbankan yang harus berkompetisi dalam dunia perbankan yang semakin ketat. Untuk dapat bersaing, PT. Bank Capital Indonesia, Tbk harus selalu meningkatkan kinerja sumber daya manusia secara efisien dan efektif. Dalam hal ini kemampuan seorang pemimpin dalam memotivasi dan mengarahkan karyawan diperlukan untuk meningkatkan kinerja karyawan. Selain itu, lingkungan kerja dalam suatu perusahaan sangat penting untuk diperhatikan oleh perusahaan manajemen. Lingkungan kerja yang memuaskan bagi karyawan perusahaan akan mendorong karyawan untuk bekerja terbaik, termasuk dalam hal layanan optimal kepada pelanggan. Sehingga kinerja karyawan yang diharapkan dapat ditingkatkan, dan tujuan perusahaan dapat dengan mudah dicapai. Data berikut dari PT. Bank Capital Indonesia, Tbk: 
Tabel 1

Data Ketidakhadiran PT. Bank Capital Indonesia, Tbk Ketidakhadiran

\begin{tabular}{|c|c|c|c|c|c|c|c|}
\hline \multirow{2}{*}{ No } & \multirow{2}{*}{ Tahun } & \multirow{2}{*}{$\begin{array}{l}\text { Jumlah } \\
\text { Pegawai }\end{array}$} & \multirow{2}{*}{$\begin{array}{c}\text { Jumlah } \\
\text { KehadiranKaryawan }\end{array}$} & \multicolumn{3}{|c|}{ Catatan } & \multirow{2}{*}{$\begin{array}{c}\text { Persentase } \\
\text { (\%) }\end{array}$} \\
\hline & & & & S & I & A & \\
\hline 1 & 2012 & 150 & 141 & 5 & 2 & 2 & 94 \\
\hline 2 & 2013 & 150 & 122 & 11 & 12 & 5 & 81.33 \\
\hline 3 & 2014 & 150 & 120 & 15 & 10 & 5 & 80 \\
\hline 4 & 2015 & 150 & 116 & 16 & 13 & 5 & 77.4 \\
\hline 5 & 2016 & 150 & 97 & 23 & 20 & $\begin{array}{l}1 \\
0\end{array}$ & 64.7 \\
\hline
\end{tabular}

Sumber: HRD PT. Bank Capital Indonesia, Tbk (2016)

Pada tahun 2014 jumlah karyawan 150 (seratus lima puluh) orang dengan jumlah karyawan yang hadir adalah 120 (seratus dua puluh) orang, di mana karyawan yang tidak tersedia karena sakit ada 15 (lima belas) orang, Izin 10 (sepuluh) orang dan Alpha 5 (lima) orang, sehingga total persentase kehadiran pada tahun 2014 adalah 80\%. Pada tahun 2015 jumlah karyawan adalah 150 (seratus lima puluh) orang dengan kehadiran 116 (seratus enam belas) orang, di mana karyawan yang absen karena sakit ada 16 (enam belas) orang, 13 (tiga belas) orang dan 135 (lima) orang, sehingga total persentase kehadiran pada tahun 2015 adalah 77,4\%.
Pada tahun 2016 jumlah karyawan tetap adalah 150 (seratus lima puluh) orang, tetapi jumlah karyawan yang ada menurun sebanyak 97 (sembilan puluh tujuh) orang dengan informasi yang tidak ada di Sakit sebanyak 23 (dua puluh tiga) orang, Lisensi 20 (dua puluh) orang dan Alfa sebanyak 10 (sepuluh) orang, sehingga pada tahun 2016 kehadiran absensi menurun 12,7\% menjadi 64,7\%. Berdasarkan informasi di atas menunjukkan bahwa kehadiran jumlah karyawan yang hadir dari 2012 hingga 2016 memiliki menurun secara signifikan, dengan informasi karyawan tidak hadir karena sakit, izin dan alpha

Tabel 2 Data Operasional Kantor Pusat Prestasi

\begin{tabular}{|c|c|c|c|c|c|c|}
\hline Tahun & $\begin{array}{c}\text { DPK } \\
(40 \%)\end{array}$ & $\begin{array}{l}\text { CASA } \\
(20 \%)\end{array}$ & $\begin{array}{c}\text { CIF } \\
(20 \%)\end{array}$ & $\begin{array}{c}\text { DOC } \\
(10 \%)\end{array}$ & $\begin{array}{c}\text { lainnya } \\
(10 \%)\end{array}$ & Skor Total \\
\hline 2012 & 80.000 & 37.000 & 175 juta & 20.000 & 1.000 & \multirow{2}{*}{83 (Sangat Baik) } \\
\hline Target & 75.000 & 50.000 & 7 & 25.000 & 1.500 & \\
\hline 2013 & 100.000 & 50.000 & 175 juta & 40.000 & 500 & \multirow{2}{*}{76 (Sangat Baik) } \\
\hline Target & 100.000 & 75.000 & 7 & 50.000 & 1.500 & \\
\hline 2014 & 100.000 & 50.000 & 250 juta & 60.000 & 1.000 & \multirow{2}{*}{74 (Baik) } \\
\hline Target & 125.000 & 75.000 & 10 & 75.000 & 3.500 & \\
\hline 2015 & 150.000 & 35.000 & 125 juta & 25,000 & 1,500 & \multirow{2}{*}{50 (Reasonable) } \\
\hline Target & 150,000 & 75,000 & 10 & 75,000 & 3,500 & \\
\hline 2016 & 125,000 & 35,000 & 175 juta & 15,000 & 1,500 & \multirow{2}{*}{42 (Under Perform) } \\
\hline Target & 175,000 & 75,000 & 10 & 75,000 & 3,500 & \\
\hline
\end{tabular}

\section{METODOLOGI}

Metode penelitian adalah deskriptif verifikatif. Penelitian ini menggunakan Regresi Berganda. Data dalam penelitian ini diperoleh dari kuesioner oleh responden yaitu karyawan bagian operasional dan bisnis di PT. Bank Capital Indonesia, Tbk di Kantor Pusat Operasional sebanyak 60 koresponden. Hal pertama yang dilakukan adalah mengetahui uraian identitas responden yang mencakup jenis kelamin, latar belakang pendidikan, masa kerja responden. 60 koresponden yang telah diteliti berdasarkan jenis kelamin, yang sebagian besar adalah wanita berjumlah 42 orang dengan persentase $70 \%$, sedangkan pria berjumlah 18 orang dengan persentase 30\%. 60 koresponden yang telah diteliti berdasarkan latar belakang pendidikan, S1 berjumlah 33 orang dengan persentase 55\%, sedangkan yang paling sedikit D3 berjumlah 8 orang dengan persentase 13,33\%. Sebanyak 60 koresponden yang telah diteliti berdasarkan lamanya bekerja, responden dengan masa kerja antara 2 dan 5 tahun paling banyak 31 orang dengan persentase 51,66\%, dan hanya 12 periode kerja lebih dari 5 tahun dengan persentase $20 \%$. Data yang digunakan dalam penelitian ini diperoleh dari 


\section{Kinerja Karyawan: Gaya Kepemimpinan, Motivasi, dan Lingkungan Kerja Di Bank (Mohammad Benny Alexandri, Meita Pragiwani, Eva Nopalina Panjaitan)}

pengisian kuesioner dengan skala likert sebanyak 60 responden. Variabel independen dalam penelitian ini adalah gaya kepemimpinan (X1), motivasi (X2), dan lingkungan kerja (X3), sedangkan variabel terikat dalam penelitian ini adalah kinerja karyawan (Y). Rata-rata pencapaian variabel gaya kepemimpinan dengan nilai tertinggi adalah 4,4, artinya PT. Bank Capital Indonesia, Tbk memiliki gaya kepemimpinan yang baik dalam bekerja. Meskipun kemampuan atasan tidak memungkinkan bawahan untuk berpartisipasi dalam pengambilan keputusan memiliki nilai terendah 2,4, biarkan pemimpin membiarkan bawahannya berpartisipasi dalam pengambilan keputusan yang terkait dengan semua pekerjaan menjadi lebih baik. Dengan demikian, hasil koresponden menunjukkan bahwa gaya kepemimpinan di PT. Bank Capital Indonesia, Tbk menerapkan gaya kepemimpinan partisipatif.

\section{DISKUSI}

Ada beberapa penelitian yang menunjukkan bahwa hubungan variabel kepemimpinan, motivasi dan lingkungan kerja terhadap kinerja karyawan memiliki hasil yang berbeda. Hal ini dibuktikan dengan penelitian yang dilakukan oleh Enrico Maramis (2013) dan Hadi Irfani (2015), di mana variabel kepemimpinan, motivasi, dan lingkungan kerja memiliki pengaruh positif yang signifikan terhadap kinerja karyawan. Sedangkan variabel penelitian ini yang diteliti adalah kepemimpinan, motivasi dan lingkungan kerja terhadap kinerja karyawan pada PT. Bank Capital Indonesia. Peran pemimpin, motivasi dan lingkungan kerja sangat penting dalam membantu kinerja karyawan untuk menghasilkan hasil yang maksimal. Namun, gaya kepemimpinan yang diterapkan harus lebih efektif untuk memenuhi tujuan perusahaan dan meningkatkan kinerja karyawan. Hal ini diperlukan untuk meningkatkan evaluasi yang dilakukan oleh para pemimpin kepada karyawan dan juga memberikan arahan dan bimbingan kepada karyawan dalam menyelesaikan tugas mereka, kebutuhan akan instruksi perusahaan tambahan dari pemimpin kepada karyawan untuk mencapai target maksimum dan efektif.

Rata-rata pencapaian variabel motivasi dengan nilai tertinggi adalah 4,5, artinya PT. Bank Capital Indonesia, Tbk memiliki motivasi kerja yang baik dalam bekerja. Meskipun keinginan karyawan yang selalu berusaha mengarahkan mitra dalam menjalankan pekerjaan memiliki nilai terendah 3,6, motivasi karyawan yang lebih baik dalam mengarahkan pasangannya lebih meningkat lagi.

Dengan mengacu pada hasil Beta (Unstandardized Coefficients) persamaan regresi linier berganda adalah:

$\hat{\mathrm{Y}}=8,767+0,247$ X $1+0,480$ X $2+0,355$ X $3+5,624$
Dengan angka positif pada konstanta, ketika ada tambahan pada variabel independen (gaya kepemimpinan, motivasi, dan lingkungan kerja), dapat menyebabkan penambahan variabel dependen (kinerja karyawan), atau kinerja sangat dipengaruhi oleh gaya kepemimpinan, motivasi, dan lingkungan kerja.

Motivasi $\left(\mathrm{X}_{2}\right)$ memiliki nilai tertinggi 0,247, yang berarti motivasi kerja karyawan PT. Bank Capital Indonesia, Tbk dalam kualifikasinya sangat signifikan. Ini menunjukkan bahwa Teori kebutuhan oleh Mc. Clelland (2012) yang membutuhkan prestasi, kebutuhan Afiliasi, dan Kebutuhan daya berhasil terbukti menunjukkan kualifikasi yang signifikan terhadap kinerja karyawan PT. Bank Capital Indonesia, Tbk. Berdasarkan pemahaman motivasi kerja dan pemahaman terhadap kinerja, motivasi kerja memiliki pengaruh terhadap kinerja jika motivasi setiap individu karyawan tinggi, akan menghasilkan semangat kerja yang tinggi pula, yang pada akhirnya akan berkontribusi dalam bentuk kinerja yang baik. Lingkungan Kerja $\left(\mathrm{X}_{3}\right)$ memiliki nilai tertinggi kedua setelah motivasi 0,355, yang berarti lingkungan kerja PT. Bank Capital Indonesia, Tbk dalam kualifikasinya adalah signifikan. Hal ini menunjukkan bahwa kondisi fisik dan bangunan kerja memberikan pengaruh terhadap kinerja karyawan, oleh karena itu penambahan dan pemeliharaan perlu meningkatkan PT. Bank Capital Indonesia, Tbk. Gaya Kepemimpinan $\left(\mathrm{X}_{1}\right)$ dengan nilai 0,247 , yang berarti gaya kepemimpinan di PT. Bank Capital Indonesia, Tbk dalam kualifikasi yang signifikan. Hal ini menunjukkan bahwa peran Interpersonal, Peran yang Informasional, dan Peran sebagai Pengambil Keputusan memiliki efek positif terhadap kinerja karyawan seperti yang dikemukakan oleh Henry Mitzberg. Hasil penelitian ini menunjukkan bahwa gaya kepemimpinan di PT. Bank Capital Indonesia, Tbk benar-benar dirasakan oleh semua karyawan dan mendorong mereka untuk melakukan aktivitas kerja.

Kinerja Karyawan PT. Bank Capital Indonesia, Tbk dalam temuannya bahwa kinerja karyawan dalam melaksanakan tugasnya adalah dengan hasil yang baik. Hal ini dapat dilihat dari pengaruh bersama gaya kepemimpinan, motivasi, dan lingkungan kerja terhadap kinerja karyawan sebesar 52,6\%, dan sisanya sebesar 47,4\% ditentukan oleh variabel lain (kompensasi, pelatihan, supervisi, disiplin kerja, dll) yang tidak diselidiki dalam penelitian ini. Kinerja yang dimaksud adalah efektivitas kerja, layanan tepat waktu dan bertanggung jawab atas pekerjaannya. Ini menunjukkan bahwa setiap tugas yang dibebankan kepada karyawan PT. Bank Capital Indonesia, Tbk dapat diselesaikan dengan hasil yang baik, tepat waktu dan dapat bermanfaat bagi PT. Bank Capital Indonesia, Tbk 


\section{Pengaruh antara Motivasi terhadap Kinerja Karyawan}

Motivasi $\left(\mathrm{X}_{2}\right)$ memiliki nilai yang paling tinggi yaitu sebesar 0.247, yang artinya motivasi kerja karyawan PT. Bank Capital Indonesia, Tbk dalam kualifikasinya sangat signifikan. Hal ini menunjukkan bahwa Theory of need oleh Mc. Clelland (2012) yaitu Kebutuhan berprestasi, Kebutuhan berafiliasi, dan Kebutuhan akan kekuasaan berhasil terbukti menunjukkan kualifikasi signifikan terhadap kinerja karyawan PT. Bank Capital Indonesia, Tbk. Berdasarkan pengertian motivasi kerja dan pengertian kinerja tersebut, maka motivasi kerja memiliki pengaruh terhadap kinerja apabila motivasi dari masingmasing individu karyawan tinggi, akan menimbulkan semangat kerja yang tinggi pula, yang pada akhirnya akan memberikan kontribusi berupa kinerja yang baik. Hal ini sejalan dengan penelitian yang telah dilakukan oleh Kadek Fajar Andika Karma, Gerianta Wirawan Yasa, Ni Made Dwi Ratnadi (2016) dalam jurnal ISSN yang berjudul Pengaruh Gaya Kepemimpinan Situasional, Budaya Organisasi dan Motivasi pada Kinerja Karyawan di PT. Bank Pembangunan Daerah Bali Cabang Badung, dimana hasilnya menunjukkan adanya pengaruh motivasi terhadap kinerja karyawan.

\section{Pengaruh antara Lingkungan Kerja terhadap Kinerja Karyawan}

Lingkungan Kerja $\left(\mathrm{X}_{3}\right)$ memiliki nilai kedua tertinggi setelah motivasi sebesar 0.355, yang berarti lingkungan kerja karyawan PT. Bank Capital Indonesia, Tbk dalam kualifikasinya tergolong signifikan. Hal ini menunjukkan bahwa kondisi fisik dan bangunan kerja memberikan pengaruh bagi kinerja karyawan, oleh karena itu penambahan dan perawatan perlu di tingkatkan PT. Bank Capital Indonesia, Tbk. Berdasarkan pengertian lingkungan kerja diatas, maka lingkungan kerja memiliki pengaruh terhadap kinerja karyawan. Hal ini sejalan dengan penelitian yang dilakukan oleh Hadi Irfani (2015) dalam jurnal ISSN yang berjudul Pengaruh Stres Kerja, Gaya Kepemimpinan, dan Lingkungan Kerja terhadap Kinerja Karyawan PT. Bank Syariah Mandiri Cabang Painan, dimana hasilnya menunjukkan adanya pengaruh lingkungan kerja terhadap kinerja karyawan.

\section{Pengaruh antara Gaya Kepemimpinan terhadap Kinerja Karyawan}

Gaya Kepemimpinan $\left(\mathrm{X}_{1}\right)$ dengan nilai sebesar 0.247, yang berarti gaya kepemimpinan di PT. Bank Capital Indonesia, Tbk dalam kualifikasi signifikan. Hal ini menunjukkan bahwa Peran yang bersifat Interpersonal, Peran yang bersifat Informasional, dan Peran sebagai Pengambil Keputusan berpengaruh positif terhadap kinerja karyawan seperti yang di kemukakan oleh Henry Mitzberg. Hasil penelitian ini menunjukkan bahwa gaya kepemimpinan di PT. Bank Capital Indonesia, Tbk betul-betul dirasakan oleh semua karyawan dan menjadikan pendorong bagi mereka untuk melakukan aktivitas pekerjaan. Berdasarkan teori diatas dapat dilihat bahwa faktor gaya kepemimpinan merupakan salah satu faktor yang paling mempengaruhi tingkat kinerja individu karyawan. Hal ini sejalan dengan penelitian yang dilakukan oleh Enrico Maramis (2013) dalam jurnal ISSN yang berjudul Kepemimpinan, Budaya Organisasi, dan Motivasi Pengaruhnya terhadap Kinerja Karyawan pada PT. Bank Tabungan Negara (Persero) Cabang Manado, dimana dari penelitian ini hasilnya menunjukkan adanya pengaruh gaya kepemimpinan terhadap kinerja karyawan.

\section{Pengaruh antara Motivasi terhadap Kinerja Karyawan}

Kinerja Karyawan PT. Bank Capital Indonesia, Tbk dalam hasil temuan ini bahwa kinerja karyawan dalam menjalankan tugasnya adalah dengan hasil yang baik. Hal ini dapat dilihat dari secara bersama-sama besarnya pengaruh gaya kepemimpinan, motivasi, dan lingkungan kerja terhadap kinerja karyawan sebesar $52.6 \%$, dan sisanya $47.4 \%$ ditentukan oleh variabel lain (kompensasi, pelatihan, pengawasan, disiplin kerja, dan lain sebagainya) yang tidak diteliti dalam penelitian ini. Kinerja yang dimaksudkan adalah efektifitas kerja, pelayanan tepat waktu dan bertanggung jawab atas pekerjaannya. Hal ini menunjukkan bahwa setiap tugas yang dibebankan kepada karyawan PT. Bank Capital Indonesia, Tbk dapat diselesaikan dengan hasil yang baik, tepat waktu dan dapat bermanfaat bagi PT. Bank Capital Indonesia, Tbk.

Dari keseluruhan pembahasan tersebut bahwa dalam penelitian kinerja karyawan di PT. Bank Capital Indonesia, Tbk, dapat dilakukan secara bertahap maupun komprehensif dengan menggunakan temuan dari hasil analisis regresi linear berganda, 


\section{Kinerja Karyawan: Gaya Kepemimpinan, Motivasi, dan Lingkungan Kerja Di Bank (Mohammad Benny Alexandri, Meita Pragiwani, Eva Nopalina Panjaitan)}

dimana faktor motivasi sebagai faktor yang paling dominan dan selanjutnya diikuti oleh faktor lingkungan kerja dan gaya kepemimpinan.

\section{KESIMPULAN}

Berdasarkan hasil analisis dan pembahasan pada bab-bab sebelumnya, maka dapat disimpulkan hal-hal berikut:

1. Gaya Kepemimpinan (X 1) dengan Beta Coefficients 0,247 nilai probabilitas (Sig) 0,020 menunjukkan signifikan, karena \& lt; 0,05, jika gaya kepemimpinan naik 1 poin, itu akan diikuti oleh peningkatan kinerja karyawan dengan nilai regresi $(0,247)$.

2. Motivasi (X 2) dengan Beta Coefficients 0,480 nilai pada probabilitas (Sig) 0,001 menunjukkan signifikan, karena \& lt; 0,05, jika motivasi naik 1 angka, itu akan diikuti oleh peningkatan kinerja karyawan dengan nilai regresi $(0,480)$.

3. Lingkungan Kerja (X 3) dengan Beta Coefficients 0,355 nilai pada probabilitas (Sig) 0,031 menunjukkan signifikan, karena \& lt; 0,05, jika lingkungan kerja naik sebesar 1 poin, maka akan diikuti oleh peningkatan kinerja karyawan dengan nilai regresi $(0,355)$.

4. R Square (Koefisien Determinasi) yang diperoleh sebesar 0,526 (52,6\%). Nilai ini mencerminkan perubahan variabel dalam kinerja variabel, di mana kinerja dapat ditentukan oleh semua variabel independen (gratis) bersama-sama 52,6\%, dan sisanya 47,4\% 2 ditentukan oleh variabel lain (kompensasi, pelatihan, pengawasan, disiplin kerja) yang tidak diteliti dalam penelitian

\section{DAFTAR PUSTAKA}

Data KPI Kantor Pusat Operasional

Fajar, Kadek Andika Karma., Gerianta Wirawan Yasa., Ni Made Dwi Ratnadi. 2016. Pengaruh Gaya Kepemimpinan Situasional, Budaya Organisasi dan Motivasi pada Kinerja Karyawan di PT. Bank Pembangunan Daerah Bali Cabang Badung. Jurnal ISSN. Volume 5. No. 11.

Irfani, Hadi. 2015. Pengaruh Stres Kerja, Gaya Kepemimpinan, dan Lingkungan Kerja terhadap Kinerja Karyawan PT. Bank Syariah Mandiri Cabang Painan. Jurnal ISSN. Volume 8. No. 2.

Maramis, Enrico. 2013. Kepemimpinan, Budaya Organisasi, dan Motivasi Pengaruhnya Terhadap Kinerja Karyawan pada PT. Bank Tabungan Negara (Persero) Cabang Manado. Jurnal ISSN EMBA. Volume 1. No. 4.

R, Belonio . 2013. Pengaruh Gaya Kepemimpinan terhadap Kepuasan Kerja dan Kinerja Pegawai Bank di Bangkok. European Journal of Work and Organization. Volume 5. No. 2.

Robbins, Stephen. P. 2006. Perilaku organisasi. Edisi Bahasa Indonesia. Indeks Kelompok Jakarta: Gramedia.

Simamora, Henry. 2006. Manajemen Sumber Daya Manusia, Edisi 2. Yogyakarta: STIE YKPN. 